\title{
INDEX TO Volume 23 (2005)
}

Articles

ALAOUI, Fouad. Le CFCM, réalité et conditions de réussite (Vol. 23, No. 1, 115)

BARTHEL-BOUCHIER, Diane and Lauretta CLOUGH. From Mondavi to Depardieu: The Global/Local Politics of Wine (Vol. 23, No. 2, 71)

BILLON, Alain. Les fondements idéologiques et les choix de la consultation (Vol. 23, No. 1, 23)

BILLON, Alain, Alain BOYER, Michèle TRIBALAT and Aslam TIMOL. L'imposition de l'État? (Vol. 23, No. 1, 119)

BOUZAR, Dounia. La première génération de Français de confession musulmane (Vol. 23, No. 1, 101)

BOYER, Alain. La représentation du culte musulman en France (Vol. 23, No. $1,8)$

BUCHSBAUM, Jonathan. After GATT: Has the Revival of French Cinema Ended? (Vol. 23, No. 3, 34)

DE GALEMBERT, Claire and Mustapha BELBAH. Le Conseil français du culte musulman à l'épreuve des territoires (Vol. 23, No. 1, 76)

GRUNBERG, Gérard. Le référendum français de ratification du Traité constitutionnel européen du 29 mai 2005 (Vol. 23, No. 3, 128)

HAYES, Graeme and Martin O'SHAUGHNESSY. Introduction: French Cinema: Globalization, Representation, and Resistance (Vol. 23, No. 3, 1)

HAYES, Graeme. Regulating Multiplexes: The French State between Corporatism and Globalization (Vol. 23, No. 3, 14)

HAYNES, Christine. The Politics of Publishing during the Second Empire: The Trial of Madame Bovary Revisited (Vol. 23, No. 2, 1)

JELEN, Brigitte. "Leur histoire est notre histoire": Immigrant Culture in France between Visibility and Invisibility (Vol. 23, No. 2, 101)

JOXE, Pierre. L'organisation de l'Islam en France: l'exemple de la Fédération protestante peut-il être utile? (Vol. 23, No. 1, 110)

KEPEL, Gilles, Fouad ALAOUI, Dounia BOUZAR, and Vianney

SEVAISTRE. Réussir les objectifs de l'État et de la religion organisée: les limites de la représentation (Vol. 23, No. 1, 122) 
LAGARDE, François. Penser l'impensable: le 11 Septembre des penseurs français (Vol. 23, No. 2, 91)

LAURENCE, Jonathan. Introduction (Vol. 23, No. 1, 1)

LAURENCE, Jonathan. From the Élysée Salon to the Table of the Republic (Vol. 23, No. 1, 37)

MARIE, Laurent. Le Réel à l'attaque: French Documentary and Globalization (Vol. 23, No. 3, 89)

MEUNIER, Sophie. Anti-Americanisms in France (Vol. 23, No. 2, 126)

MICHAEL, Charlie. French National Cinema and the Martial Arts Blockbuster (Vol. 23, No. 3, 55)

O'SHAUGHNESSY, Martin. Eloquent Fragments: French Fiction Film and Globalization (Vol. 23, No. 3, 75)

ROZEIRA DE MARIZ, Frederic. Le Portugal de Salazar et la droite extrême française, 1928-1945 (Vol. 23, No. 2, 28)

SCOTT, Joan W. Symptomatic Politics: The Banning of Islamic Head Scarves in French Public Schools (Vol. 23, No. 3, 106)

SEVAISTRE, Vianney. Les relations entre le Conseil français du culture musulman et l'État: quelle nature? (Vol. 23, No. 1, 66)

VENEL, Nancy. Francités, islamités: compositions citoyennes et religieuses des jeunes musulmans français d'origine maghrébine (Vol. 23, No. 1, 88)

WILLERTON, John P. and Martin CARRIER. Jospin, Political Cohabitation and Left Governance (Vol. 23, No. 2, 43)

Review Essay

KNOX, Edward C. Uncle Sam and Marianne as Couple Infernal (Vol. 23, No. $3,145)$

\section{Book Reviews}

ACKERMAN, Evelyn Bernadette. Liberalism under Siege: The Political Thought of the French Doctrinaires by Aurelian Craiutu (Vol. 23, No. 1, 130)

AUSLANDER, Leora. Marianne in the Market: Envisioning Consumer Society in Fin-de-Siècle France by Lisa Tiersten (Vol. 23, No. 3, 151)

BAUMGARTNER, Frank R. Party, Society, Government: Republican Democracy in France by David Hanley (Vol. 23, No. 1, 155)

COGAN, Charles. Qui a tué Daniel Pearl? by Bernard-Henri Lévy (Vol. 23, No. 1, 166)

COWANS, Jon. Making Jazz French: Music and Modern Life in Interwar Paris by Jeffrey H. Jackson (Vol. 23, No. 1, 141)

GUNTHER, Scott. Liberté, égalité, sexualités: Actualité politique des questions sexuelles by Clarisse Fabre and Eric Fassin (Vol. 23, No. 3, 166)

HARGREAVES, Alec G. Muslims and the State in Britain, France and Germany by Joel S. Fetzer and J. Christopher Soper (Vol. 23, No. 3, 169) 
HAZAREESINGH, Sudhir. Funerals, Politics, and Memory in Modern France, 1789-1996 by Avner Ben-Amos (Vol. 23, No. 1, 132)

JACKSON, Jeffrey H. Django: The Life and Music of a Gypsy Legend by Michael Dregni (Vol. 23, No. 3, 157)

KRAMER, Lloyd. Enlightenment Phantasies: Cultural Identity in France and Germany, 1750-1914 by Harold Mah (Vol. 23, No. 2, 142)

LEWIS, Mary D. In the Aftermath of Genocide: Armenians and Jews in Twentieth-Century France by Maud S. Mandel (Vol. 23, No. 1, 145)

MARKOVITS, Andrei S. Football in France: A Cultural History by Geoff Hare (Vol. 23, No. 1, 161)

MATHY, Jean-Philippe. Camus \& Sartre: The Story of a Friendship and the Quarrel That Ended It by Ronald Aronson (Vol. 23, No. 3, 159)

MERLE, Isabelle. Exile to Paradise: Savagery and Civilization in Paris and the South Pacific 1790-1900 by Alice Bullard (Vol. 23, No. 1, 135)

OPELLO, Katherine. French Women in Politics: Writing Power, Paternal Legitimation, and Maternal Legacies by Raylene L. Ramsey (Vol. 23, No. 1, 159)

PRITCHARD, Sara B. The Light-Green Society: Ecology and Technological Modernity in France, 1960-2000 by Michael Bess (Vol. 23, No. 1, 148)

REVILL, Joel. The Seduction of Unreason: The Intellectual Romance with Fascism from Nietzsche to Postmodernism by Richard Wolin (Vol. 23, No. 3, 163)

ROGERS, Rebecca. Disruptive Acts: The New Woman in Fin-de-Siècle France by Mary Louise Roberts (Vol. 23, No. 3, 153)

SHEPARD, Todd. France and Algeria: A History of Decolonization and Transformation by Phillip C. Naylor (Vol. 23, No. 1, 152)

SURKIS, Judith. Jews and Gender in Liberation France by K.H. Adler (Vol. 23, No. 2, 149)

VIGUIER, Frédéric. Violences urbaines, violence sociale. Genèse des nouvelles classes dangereuses by Stéphane Beaud and Michel Pialoux (Vol. 23, No. 2, 151)

WELCH, Cheryl B. L'Impensé de la démocratie: Tocqueville, la citoyenneté et la religion by Agnès Antoine (Vol. 23, No. 2, 145)

\section{INDEX OF BOOKS REVIEWED}

ADLER, K.H. Jews and Gender in Liberation France reviewed by Judith Surkis (Vol. 23, No. 2, 149)

ANTOINE, Agnès. L'Impensé de la démocratie: Tocqueville, la citoyenneté et la religion reviewed by Cheryl Welch (Vol. 23, No. 2, 145)

ARONSON, Ronald. Camus \& Sartre: The Story of a Friendship and the Quarrel That Ended It reviewed by Jean-Philippe Mathy (Vol. 23, No. 3, 159)

BEAUD, Stéphane and Michel PIALOUX. Violences urbaines, violence sociale. Genèse des nouvelles classes dangereuses reviewed by Frédéric Viguier (Vol. 23, No. 2, 151) 
BEN-AMOS, Avner. Funerals, Politics, and Memory in Modern France, 17891996 reviewed by Sudhir Hazareesingh (Vol. 23, No. 1, 132)

BESS, Michael. The Light-Green Society: Ecology and Technological Modernity in France, 1960-2000 reviewed by Sara B. Pritchard (Vol. 23, No. 1, 148)

BULLARD, Alice. Exile to Paradise: Savagery and Civilization in Paris and the South Pacific 1790-1900 reviewed by Isabelle Merle (Vol. 23, No. 1, 135)

CRAIUTU, Aurelian. Liberalism under Siege: The Political Thought of the French Doctrinaires reviewed by Evelyn Bernadette Ackerman (Vol. 23, No. 1, 130)

DREGNI, Michael. Django: The Life and Music of a Gypsy Legend reviewed by Jeffrey H. Jackson (Vol. 23, No. 3, 157)

FABRE, Clarisse and Eric FASSIN. Liberté, égalité, sexualités: Actualité politique des questions sexuelles reviewed by Scott Gunther (Vol. 23, No. 3, 166)

FETZER, Joel S. and J. Christopher SOPER. Muslims and the State in Britain, France and Germany reviewed by Alec G. Hargreaves (Vol. 23, No. 3, 169)

HANLEY, David. Party, Society, Government: Republican Democracy in France reviewed by Frank R. Baumgartner (Vol. 23, No. 1, 155)

HARE, Geoff. Football in France: A Cultural History reviewed by Andrei S. Markovits (Vol. 23, No. 1, 161)

JACKSON, Jeffrey H. Making Jazz French: Music and Modern Life in Interwar Paris reviewed by Jon Cowans (Vol. 23, No. 1, 141)

LÉVY, Bernard-Henri. Qui a tué Daniel Pearl? reviewed by Charles Cogan (Vol. 23, No. 1, 166)

MAH, Harold. Enlightenment Phantasies: Cultural Identity in France and Germany, 1750-1914 reviewed by Lloyd Kramer (Vol. 23, No. 2, 142)

MANDEL, Maud S. In the Aftermath of Genocide: Armenians and Jews in Twentieth-Century France reviewed by Mary D. Lewis (Vol. 23, No. 1, 145)

NAYLOR, Phillip C. France and Algeria: A History of Decolonization and Transformation reviewed by Todd Shepard (Vol. 23, No. 1, 152)

RAMSEY, Raylene L. French Women in Politics: Writing Power, Paternal Legitimation and Maternal Legacies reviewed by Katherine Opello (Vol. 23, No. 1, 159)

ROBERTS, Mary Louise. Disruptive Acts: The New Woman in Fin-de-Siècle France reviewed by Rebecca Rogers (Vol. 23, No. 3, 153)

TIERSTEN, Lisa. Marianne in the Market: Envisioning Consumer Society in Fin-de-Siècle France reviewed by Leora Auslander (Vol. 23, No. 3, 151)

WOLIN, Richard. The Seduction of Unreason: The Intellectual Romance with Fascism from Nietzsche to Postmodernism reviewed by Joel Revill (Vol. 23, No. 3, 163) 